Linguista: Jurnal Ilmiah Bahasa, Sastra, dan Pembelajarannya

Vol.3, No.1, Juni 2019, hal 59 - 68

ISSN (print): 2579-8944; ISSN (online): 2579-9037

Avaliable online at: http://e-journal.unipma.ac.id/index.php/linguista

\title{
PBL on Learning Reading Text for Enhancing Learner's Speaking Ability
}

\author{
Yudi Hari Riyanto \\ STKIP PGRI Pasuruan, Jalan Ki Hajar Dewantara 27-29, Kota Pasuruan, Indonesia \\ e-mail: rayanto75@gmail.com
}

\begin{abstract}
This research is conducted in the teaching and learning process toward the college students during 6 meetings. The teaching and learning itself uses a reading text as one of media to enhance the learner's speaking ability. In this case, the problems which exist in the reading text must be overcome by college students altogether. Here, the lecturer implements PBL as one of the strategy. The purposes of this research are to find out (1) how effective is the implementation of $P B L$ on learning reading text for enhancing learner's speaking ability, and (2) how is the learner's activity and the result of speaking performance test during the implementation of $P B L$ on learning reading text for enhancing learner's speaking ability. The data were gained from observation from two observers and test given to college students in each meetings. All data were analyzed by using descriptive quantitative study. From the result of observation and test which were already obtained and calculated by researcher, it shows that the effectiveness of $P B L$ is in high level, that is 3,96. It can be said that the learning process is effective to be implemented and for students' activity during the implementation of PBL is also categorized high, that 3,86. Meanwhile, the result of college student's learning achievement can also be categorized high, all students get satisfying and excellent score.
\end{abstract}

Keywords: Designing; Reading; PBL; Focal Point

\section{Introduction}

Designing and managing a good classroom and activity in teaching and learning is invariably stated as a lecturer's task. For common people, simply it can be said that designing a classroom as a place of learning is easy because it only needs financial, some tools or infrastructure for making it comes true. As a matter of fact, it differs from designing a classroom as an activity on learning, especially for lecturer and college students. This is because changing the ways of college students on learning are not fixed at birth, but it must be well prepared. For instance, in such a class, college students must be convinced that as one of the part of their purpose on learning is to gain its success. For making it true is by persuading college students, that there has to be a feedback between college students and lecturer on learning. Therefore for lecturer itself requires method, strategy and technique whereas each lecturer has his own ways on implementing it.

Indeed, one of things which must be well prepared by lecturer is implementing as beautiful as possible of his strategy or techniques on learning. Moreover, lecturer has to design and manage his/her a classroom in order for having a good atmosphere on teaching and learning. It actually is not as easy as we thought. As already known, on teaching and learning a lecturer does not only convey the material but also has to know 
the characteristics of learners. In another words, in conveying and elaborating material in the classroom, the lecturer has to be ready in all cases by planning and preparing everything he/she needs on his/her learning. A lecturer has to make difficult material to be understood and comprehended easily by the students. Internally, a lecturer has to be able to develop his/her creativity on learning. Strategy, methods and techniques are really needed by lecturer when she/he performs in front of his/her learners. Meanwhile, externally a lecturer has to be aware that his/her learners have their own types of uniqueness on their ways of thinking. Therefore, a lecturer has to have capability to recognize the dimension of learners' learning if he/she wants to be a successful lecturer. As stated by Pickering, Blackburn and Moffet (1992), the dimensions of learning have functions to create or develop positive attitude and good perception about learning, help students to acquire and integrate new knowledge, extending and refining the knowledge, involving them in using knowledge meaningfully and the most effective learners have developed powerful habits of mind that enable them to regulate their behavior, think critically, and think creatively. It is a must for all lecturers to do these dimensions, if all aspects mentioned above have not been done, the atmosphere of the learning itself can be categorized questionable. According to constructionists, the college students are also designers, not merely receivers of designed material and activities. During the design phase, the college students establishes individual learning goals, evaluates and decides whether to engage in potential sequences of learning activities (including group interactions and individual work), locates and evaluates potential resources, and chooses methods to assess the solution to the problem posed, Reiser \& Dempsey(2002, 78).

Therefore, on engaging and interacting learners in a classroom, a lecturer needs to use some approaches on learning. One of the approaches which can be used here is PBL (Problem Based Learning). PBL is one of the constructivist approaches whereas its learning environment focuses on the authenticity of learners in their activity based on the discipline of their own learning. Collaboration is really needed and give a vast opportunity to link multiple perspectives on what is being learned, support students in determining their own purposes and mapping and controlling their own learning, and doing reflection on what and how they are learning. As also stated by Wilson (1995,p 27) Constructivist learning environments create a place where learners may work together and support each other as they use a variety of tools and information resources in their pursuit of learning goals and problem solving activities. It is also emphasized by Barrows (1998) whereas the authenticity of PBL as addressing several educational objectives such as; acquisition of deeply understood knowledge integrated from a variety of disciplines, development of effective clinical problem-solving, development of self-directed learning, development of team and interpersonal skills, and development of a desire to continually learn. Apart from what has been mentioned, Arends (2004) presents five model or syntax of PBL which must be done by lecturer to his/her learners, such as (1) the process begins with orientating students to the problem (go over the objectives of the lesson, describes important logistical requirements, and motivates students to engage in self-selected problem-solving activity), (2) followed by the set up of groups for study (help students define and organize study tasks related to the problem), (3) assist independent group investigation (encourage students to gather appropriate information, conduct experiments, and search for explanations and solutions), (4) develop and present 
artifacts and exhibits (assist student in planning and preparing appropriate artifacts such as reports, videos, and models and helps them share their work with others), and (5) analyze and evaluate the problem-solving process (teacher helps students to reflect on their investigations and the processes they used)

Many researches have already been conducted through the implementation of PBL itself on teaching and learning. One of them is from Grzeskowiak, Podlewski, Koska, Zaba, and Drobnik (2009) whereas the research was undertaken in 2002 in accordance with the European Guidelines 2000 and involved 36 medical students in year 4 . The students were divided into two groups: experimental PBL group (17 students) and the control-classical method group (19 students). The experimental PBL group received significantly better results: $30-45$ points (mean, 38.29 points) and 30-47 points (mean, 40.94 points) for the written and practical tests, respectively, compared with the controlclassical group (22-34 points [mean, 29.36 points] and 22-35 points [mean, 28.63 points], respectively). Therefore, PBL offers a better method for teaching basic and advanced life support to medical students compared with the classical method. Another research is from Dodd (2007) whereas this research was conducted on the impact of Problem-Based Learning (PBL) on the information seeking and literacy of veterinary students at University College Dublin. Data were collected using both quantitative and qualitative methods from students, academics and the librarian. Results showed that PBL has a significant impact on how students find and use information.

Recognizing the successfulness of PBL on teaching and learning, the researcher here is interested to do a similar research, but in different field that is Reading text for enhancing student's speaking ability. Reading is the process of extracting and constructing meaning from text. This is a complex interactive process that involves many bottom-up as well as top-down sub processes at the word, sentence and text levels, Tunmer (2008). The interactive process on a learning in the classroom needs special skill from the lecturer itself. A Lecturer is able to use two kinds of technique for its learning such as through silent reading and reading aloud. Both of them can be used to gain the learning objectives. Concluding from Hedge (2008) in Delfi \&Yamat (2017) there are some general learning goals for the reading component, they are to build up a knowledge of language (vocabulary and structure) which will facilitate development of greater reading ability on extracting and constructing meaning from the text. It can be categorized as the silent reading. Besides that, it can also be categorized reading aloud when the purpose is to adapt reading syle according to range of purposes. Adapting reading style here, in the classroom both between lecturer and students have to have ability on adapting and practicing proper word. Especially when learners must produce or utter the word properly.

Uttering words or sentences in reading learning actually is not something odd anymore. This learning perhaps can be called as a traditional technique. A Lecturer commonly uses this learning style through asking learners to utter sentence by sentence on reading learning. When there is something matters happen in learners' pronunciation, lecturer itself can revise it until its pronunciation can be said be much better. Some different approaches have been conducted by some researchers and they also found their own difference conclusion. Tunmer (2008) states that the differences between these approaches represent various ideas as to efficient and effective ways to acquire reading skills. The main distinction between the different approach reading instructions concerns 
the emphasis given to the direct instruction of the alphabetic principle and the strategies acquired for text analysis. The traditional approach reading instructions, known as the phonic approach, emphasizes the identification of fundamental components of the word and their memorization through bottom-up processes. Thus, this approach focuses on the learning of the sounds of letters by repetition and practice, Treiman (2001).

This learning perhaps already be done mostly by the lecturers, but also they are not aware that the learning taken can be used to enhance learners' speaking ability. Speaking refers to the ability to speak effectively in different contexts to give information, to express ideas, and feelings, as well as to build social relationship in the form of activities which are various in nature, interactive, and interesting. To make the college students can speak effectively, a lecturer can give reading text material as media. In other words, when college students have material taken from reading text material to be expressed, they can effectively explore them well. Simply it can be conducted by lecturer to make college students enhance their speaking ability. On learning, as the procedure, a lecturer can ask some college students to read the reading text by heart, try to pronounce some difficulties words which are given in reading text. Then, a lecturer can ask some college students to read aloud. If the process of reading finds some improper pronunciation, the lecturer must improve the college students' pronunciation. After reading aloud conducted, the lecturer can ask some question through personal question orally based on the content of the reading text individually to the students. In this such occasion, lecturer is able to see, notice and recognize learner's ability on speaking. In this case, the lecturer can give score.

\section{Method}

This study whereas all aspects gained from the instruments, they were observation sheets and test was counted quantitatively. Meanwhile the procedure for obtaining the data were through the use of three focal points from C-ID Willis (2000), they were define, design and development, and dissemination.

\section{Define}

At this phase, first, the researcher determined the place of the research, college learners, and observers. All these components are from STKIP PGRI Pasuruan, East Java Indonesia. The college learners were from academic year 2017, the number was 27 and the observers consisted of two observers. Second, define the topic or theme of problems from reading material text which was discussed. Third, define a team of study from the learners themselves. It consisted of $5 / 6$ members in each group.

\section{Design and development}

Before the learning process was conducted, first, the researcher designed each team for having a leader. The leader was chosen through learners' discussion in each group. The leader must organize his/her member for determining solution from the problems given. Second, design the evaluation procedure. In this case, the researcher asked the two observers to notice and score researcher's and college learners' activity during the learning process (observation sheets) and gave oral question (test) in every meeting whereas the score was obtained from learner's speaking performance based on scoring rubric/assessment. 
After designing was done, the researcher developed the learning process through (1) assisting independent group investigation (encourage learners by accommodating and walking around in every group for searching some difficulties words and its pronunciation, contextual and lexical meaning of sentence, scanning and skimming of the reading material text, to gather appropriate information from reading material text through inference based on learner's prior knowledge and other real scientific sources, and search for explanations and solutions), (2) developing and presenting the finding of difficulties words and its pronunciation by exercising themselves in each group before speaking performance conducted by lecturer by way of questioning. Besides that, the lecturer assists learners in enhancing its pronunciation, planning and preparing appropriate answers or artifacts such as reports and helps them share their work with others), and (3) analyzing and evaluating the problem-solving process through the result of prior knowledge of learners, and scientific source whereas these components were gained from learner's discussion based on the problems given by lecturer in reading material text. In this case, the lecturer helped learners to reflect on their finding of investigation.

\section{Dissemination}

On reflecting the learner's result based on the problems given and for gaining the enhancement of learner's speaking ability, the lecturer asked some question through personal question orally. The questions were divided into learner's prior knowledge and the content of the text. The question was given randomly to learners in every group. If the learner could not answer the question given, the lecturer could throw the question to another group. It encouraged and enhanced learners to speak English spontaneously and simultaneously.

\section{Result and Discussion}

\section{The Effectiveness of PBL}

For recognizing the effectiveness of PBL, the researcher uses all data from observation sheets gained from two observers (lecturer's and learners' activity) and learner's result test, then the researcher calculates and counts the result as follows:

Table 1. Data and analysis data from lecturer's learning process

\begin{tabular}{|c|c|c|c|c|c|c|c|c|c|c|c|c|c|c|}
\hline \multirow{4}{*}{$\begin{array}{l}\text { Aspect } \\
\text { Number }\end{array}$} & \multicolumn{12}{|c|}{ Meeting from- } & \multirow[t]{2}{*}{$\overline{\bar{I}_{\bar{I}}}$} & \multirow{4}{*}{$\overline{P_{k}}$} \\
\hline & \multicolumn{2}{|c|}{1} & \multicolumn{2}{|c|}{2} & \multicolumn{2}{|c|}{3} & \multirow{2}{*}{\multicolumn{2}{|c|}{4}} & \multicolumn{2}{|c|}{5} & \multicolumn{2}{|c|}{6} & & \\
\hline & & & & ult & $\mathrm{ob}$ & erv & & rom & bs & rve & & & & \\
\hline & 1 & 2 & 1 & 2 & 1 & 2 & 1 & 2 & 1 & 2 & 1 & 2 & & \\
\hline 1 & 4 & 3 & 3 & 4 & 4 & 4 & 4 & 4 & 4 & 4 & 4 & 4 & 3,9 & \\
\hline 2 & 4 & 4 & 4 & 4 & 4 & 4 & 4 & 4 & 4 & 4 & 4 & 4 & 4,0 & \\
\hline 3 & 4 & 4 & 4 & 4 & 4 & 4 & 4 & 4 & 4 & 4 & 4 & 4 & 4,0 & 3,96 \\
\hline 4 & 4 & 4 & 4 & 4 & 4 & 4 & 4 & 4 & 4 & 4 & 4 & 4 & 4,0 & \\
\hline 5 & 3 & 4 & 4 & 3 & 4 & 4 & 4 & 4 & 4 & 4 & 4 & 4 & 3,9 & \\
\hline
\end{tabular}

From the calculation above, it can be seen that there are similar and different score given by two observers. The similarities score can be seen from aspect number 2 , 
3 and 4 for all meetings. Both of observers give 4 . Meanwhile, the difference score can be seen from aspect number 1 and 5 . Observer 1 gives 3 for aspect number 5 at the first meeting and 3 for aspect number 1 at the second meeting. Thus, second observer gives 3 in meeting 1 for aspect number 1 and aspects number 5 at the second meeting. After all scores are calculated, the effectiveness of this learning process shows in high level, that is 3.96. It means that PBL on reading text for enhancing learner's speaking ability is effective.

Table 2. Data and analysis data from learner's activity

\begin{tabular}{|c|c|c|c|c|c|c|c|c|c|c|c|c|c|c|c|}
\hline Aspects & \multicolumn{12}{|c|}{ Meeting- } & \multirow{4}{*}{$\overline{P_{i}}$} & \multirow{4}{*}{$\overline{A_{j}}$} & \multirow{4}{*}{$\overline{a_{k}}$} \\
\hline \multirow[t]{3}{*}{ Number } & \multicolumn{2}{|c|}{1} & \multicolumn{2}{|c|}{2} & \multicolumn{2}{|c|}{3} & \multicolumn{2}{|c|}{4} & \multicolumn{2}{|c|}{5} & \multicolumn{2}{|c|}{6} & & & \\
\hline & \multicolumn{12}{|c|}{ Observer number- } & & & \\
\hline & 1 & 2 & 1 & 2 & 1 & 2 & 1 & 2 & 1 & 2 & 1 & 2 & & & \\
\hline 1 & 4 & 4 & 4 & 4 & 3 & 4 & 4 & 4 & 4 & 4 & 4 & 4 & 3,9 & 3,9 & \\
\hline 2 & 3 & 4 & 4 & 4 & 4 & 4 & 4 & 4 & 4 & 4 & 4 & 4 & 3,9 & 3,9 & \\
\hline 3 & 4 & 4 & 4 & 4 & 4 & 3 & 4 & 4 & 4 & 4 & 4 & 4 & 3,9 & 3,9 & \\
\hline 4 & 4 & 3 & 4 & 4 & 4 & 4 & 4 & 4 & 4 & 4 & 4 & 4 & 3,9 & 3,9 & \\
\hline 5 & 4 & 4 & 4 & 3 & 4 & 3 & 4 & 4 & 4 & 4 & 4 & 4 & 3,8 & 3,8 & \\
\hline 6 & 4 & 4 & 4 & 4 & 3 & 4 & 4 & 4 & 4 & 4 & 4 & 4 & 3,9 & 3,9 & \\
\hline 7 & 3 & 4 & 4 & 4 & 4 & 4 & 3 & 4 & 4 & 4 & 4 & 4 & 3,8 & 3,8 & 3,86 \\
\hline 8 & 4 & 3 & 4 & 4 & 4 & 3 & 4 & 4 & 4 & 4 & 4 & 4 & 3,8 & 3,8 & \\
\hline 9 & 4 & 4 & 4 & 3 & 4 & 4 & 4 & 4 & 4 & 4 & 4 & 4 & 3,9 & 3,9 & \\
\hline 10 & 4 & 3 & 4 & 4 & 4 & 4 & 4 & 4 & 4 & 4 & 4 & 4 & 3,9 & 3,9 & \\
\hline 11 & 4 & 4 & 3 & 4 & 4 & 4 & 3 & 4 & 4 & 4 & 4 & 4 & 3,8 & 3,8 & \\
\hline 12 & 3 & 4 & 4 & 4 & 4 & 4 & 4 & 4 & 4 & 4 & 4 & 4 & 3,9 & 3,9 & \\
\hline
\end{tabular}

From the calculation above, it can be seen vividly that there are similar and different score given by two observers. The similarities can be seen from meeting 5 and 6 , whereas all aspects are 4 given by two observers. Meanwhile, the differences can also be seen such as; Observer 1 gives 3 for aspect number 2, 7 and 12 for meeting 1, for meeting 2 in aspect number 11, in meeting 3 for aspects number 1 and 6 , and in meeting 4 for aspects number 7 and 11. Moreover, the second observer gives 3 in meeting 1 for aspect number 8,10 , meeting 2 for aspect number 5 and 9 and meeting 3 for aspects number 3,5 and 8 .

Meanwhile, from the calculation above, it can be said that the result can be categorized high, that is 3,86 . It means that the learners have high activity during the implementation of PBL on reading text for enhancing learner's speaking ability. So, it can also be categorised that PBL is effective to be implemented in classroom. 
Table 3. Data and analysis data from learners' learning achievement

\begin{tabular}{|c|c|c|c|c|c|c|c|c|}
\hline \multirow{4}{*}{$\begin{array}{l}\text { Learner's } \\
\text { Attendance } \\
\text { number }\end{array}$} & \multicolumn{6}{|c|}{ Meeting- } & \multirow[b]{4}{*}{ Total } & \multirow[b]{4}{*}{$\begin{array}{l}\text { Final } \\
\text { Score }\end{array}$} \\
\hline & 1 & 2 & 3 & 4 & 5 & 6 & & \\
\hline & \multicolumn{6}{|c|}{ Evaluation score from meeting- } & & \\
\hline & 1 & 2 & 3 & 4 & 5 & 6 & & \\
\hline 1 & 88 & 92 & 94 & 97 & 95 & 86 & 552 & 92 \\
\hline 2 & 94 & 92 & 93 & 97 & 96 & 86 & 558 & 93 \\
\hline 3 & 82 & 90 & 93 & 95 & 94 & 83 & 537 & 90 \\
\hline 4 & 85 & 90 & 94 & 96 & 93 & 86 & 544 & 91 \\
\hline 5 & 85 & 89 & 93 & 97 & 95 & 86 & 545 & 91 \\
\hline 6 & 91 & 92 & 96 & 98 & 94 & 86 & 557 & 93 \\
\hline 7 & 91 & 89 & 94 & 97 & 94 & 86 & 551 & 92 \\
\hline 8 & 82 & 90 & 93 & 96 & 95 & 83 & 539 & 90 \\
\hline 9 & 82 & 89 & 93 & 94 & 92 & 86 & 536 & 89 \\
\hline 10 & 82 & 90 & 96 & 95 & 91 & 90 & 544 & 91 \\
\hline 11 & 88 & 89 & 93 & 98 & 96 & 86 & 550 & 92 \\
\hline 12 & 82 & 89 & 93 & 94 & 92 & 86 & 536 & 89 \\
\hline 13 & 91 & 89 & 94 & 97 & 94 & 86 & 551 & 92 \\
\hline 14 & 88 & 94 & 94 & 98 & 96 & 86 & 556 & 93 \\
\hline 15 & 88 & 89 & 96 & 97 & 94 & 86 & 550 & 92 \\
\hline 16 & 85 & 92 & 94 & 97 & 95 & 90 & 553 & 92 \\
\hline 17 & 91 & 90 & 93 & 96 & 95 & 86 & 551 & 92 \\
\hline 18 & 91 & 89 & 94 & 97 & 96 & 86 & 553 & 92 \\
\hline 19 & 88 & 92 & 96 & 95 & 96 & 90 & 557 & 93 \\
\hline 20 & 82 & 89 & 92 & 95 & 91 & 86 & 535 & 89 \\
\hline 21 & 85 & 89 & 93 & 96 & 95 & 90 & 548 & 91 \\
\hline 22 & 94 & 96 & 93 & 96 & 95 & 90 & 564 & 94 \\
\hline 23 & 85 & 94 & 93 & 97 & 95 & 90 & 554 & 92 \\
\hline 24 & 82 & 89 & 94 & 94 & 95 & 90 & 544 & 91 \\
\hline 25 & 88 & 89 & 96 & 95 & 93 & 90 & 551 & 92 \\
\hline 26 & 85 & 90 & 92 & 97 & 93 & 90 & 547 & 91 \\
\hline 27 & 88 & 92 & 94 & 95 & 96 & 86 & 551 & 92 \\
\hline
\end{tabular}

The score above is gained from learner's test performance in every meeting of the lesson. From the table above, it can be seen that there are only 3 learners got under 90 that is attendance list number 9, 12, and 20, and others got more. After all scores are calculated from first until last test, it can be said that more than $90 \%$ learners are success on doing speaking performance test through the implementation of PBL. It is because all students mostly get more than 90 .

Learning will run smoothly if the components of learning are well prepared. These components consist of lecturer, college students, and infrastructure. As the instance; lecturer must prepare his media, strategy, lesson plan, etc, and college students must 
be ready with all apparatus they need, not only the hard (book, electronic learning) but also their psychology (mental, motivation). Meanwhile, college itself must provide the learners with its infrastructure. In another words, all those components are blended for making the smooth learning comes true.

A good atmosphere in learning process will create a critical and creative thinking not only for students but also lecturers. So, the effective and high achievement on learning process can be obtained. Therefore, lecturer must prepare his learning tools, such as lesson plan, material, media, and its strategy before learning process conducted. In the classroom, strategy is the main fundamental, based on the result of research (Dole, Brown, \& Trathen, 1996; Janzen,2003; Karbalaei \&Rajyashree, 2010; Khoshsima \& Rezaeian, 2014; Pakzadian \& Eslami Rasekh, 2012; Nurhayati, 2014; Roohani, et al., 2015; Deshpande, 2016; Teng, 2016; Damayanti, 2017) in Maybodi \& Maibodi (2017) states that together with direct instructions when students are taught reading strategies this will improve not only their comprehension of the reading passage but also their performance on the tests. Surely, the test itself can be various. In this case is a speaking test. Meanwhile, for college students themselves, they should participate and take part in learning process itself. Here, simply for arousing students' participation and making the learning process effective, the lecturer should give a broad chance to college students to construct their own learning and to solve the problems occur. Of course, it is found in PBL. Here, students must be mixed to be one body (learners) for working, communicating, cooperating, and collaborating in learning process for solving and creating effective learning. In other words, lecturer and college students must collaborate in learning process for avoiding boredom. As stated by Mustadji, (2009) in constructivist approach sees that students individually and or collaboratively can construct their own knowledge. In other words, the core of constructivism is authentic learning, Nemati (2016). But, if the lecturer and college students do not know their position, the learning process cannot run well. According to Ardhana (1997) and Degeng (1999), the less of its optimal in teaching process because (1) lecturers are unable to conduct the learning process which is in line with the development of instructional technology, (2) lecturers have a negative perception or misunderstanding about a learning process, (3) lecturers use learning concept which is not relevant with the development of instructional technology. So, if they did well (lecturer and college students) the goal of learning is easy enough to be gained.

\section{Conclusion}

Learning will run smoothly if the components of learning are well prepared. These components consist of lecturer, college students, and infrastructure. As the instance; lecturer must prepare his media, strategy, lesson plan, etc, and college students must be ready with all apparatus they need, not only the hard (book, electronic learning) but also their psychology (mental, motivation). Meanwhile, college itself must provide the learners with its infrastructure. In another words, all those components are blended for making the smooth learning comes true.

A good atmosphere in learning process will create a critical and creative thinking not only for students but also lecturers. So, the effective and high achievement on learning process can be obtained. Therefore, lecturer must prepare his learning tools, such as lesson plan, material, media, and its strategy before learning process conducted. 
In the classroom, strategy is the main fundamental, based on the result of research (Dole, Brown, \& Trathen, 1996; Janzen,2003; Karbalaei \&Rajyashree, 2010; Khoshsima \& Rezaeian, 2014; Pakzadian \& Eslami Rasekh, 2012; Nurhayati, 2014; Roohani, et al., 2015; Deshpande, 2016; Teng, 2016; Damayanti, 2017) in Maybodi \& Maibodi (2017) states that together with direct instructions when students are taught reading strategies this will improve not only their comprehension of the reading passage but also their performance on the tests. Surely, the test itself can be various. In this case is a speaking test. Meanwhile, for college students themselves, they should participate and take part in learning process itself. Here, simply for arousing students' participation and making the learning process effective, the lecturer should give a broad chance to college students to construct their own learning and to solve the problems occur. Of course, it is found in PBL. Here, students must be mixed to be one body (learners) for working, communicating, cooperating, and collaborating in learning process for solving and creating effective learning. In other words, lecturer and college students must collaborate in learning process for avoiding boredom. As stated by Mustadji, (2009) in constructivist approach sees that students individually and or collaboratively can construct their own knowledge. In other words, the core of constructivism is authentic learning, Nemati (2016). But, if the lecturer and college students do not know their position, the learning process cannot run well. According to Ardhana (1997) and Degeng (1999), the less of its optimal in teaching process because (1) lecturers are unable to conduct the learning process which is in line with the development of instructional technology, (2) lecturers have a negative perception or misunderstanding about a learning process, (3) lecturers use learning concept which is not relevant with the development of instructional technology. So, if they did well (lecturer and college students) the goal of learning is easy enough to be gained.

\section{References}

Ardhana, W. (1997). Pandangan Konstruktivistik Tentang Pemecahan Masalah Belajar. Makalah Seminar TEP PPS IKIP Malang.

Arends, R. I. (2004). Classroom instruction and management. Boston: McGraw Hill.

Barrows, H. S. (1998). The essentials of problem-based learning. Journal of Dental Education, 62(9), 630-633

Degeng, N.S. (1999). Mencari Pendekatan Baru Pememcahan Masalah Belajar, Jayapura: Yayasan Jayawijaya, Kuala Kencana PT. Freeport Indonesia.

Delfi, Syofia \& Yamat, Hamidah. (2017). Extensive Reading in Developing English Competency for Indonesian EFL Learners Majoring in English. IJELTAL (Indonesian Journal of English Language Teaching and Applied Linguistics), 1(2), 2017.

Dodd, L. (2007) The impact of Problem-Based Learning on the Information Seeking Behaviour and Information Literacy of Veterinary Medicine Students at University College Dublin', Journal of Academic Librarianship, 33(2), 206-21

Grzeskowiak, Podlewski, Koska, Zaba, and Drobnik (2009). Problem Based Learning as a method of Teaching Learning at the University of Medical Sciences in Poznan, Poland 
Maybodi, A. S. P. \& Maibodi, A.H. (2017). The Effect of Teaching Summarization Strategies on Reading Comprehension of Science and Humanities Iranian High School Students. Indonesian Journal of EFL and Linguistics, 2(1), 2017

Mustaji. (2009). Pengembangan Model Pembelajaran Berbasis Malah Dengan Pola Kolaborasi Dalam Mata Kuliah Masalah Sosial, ProgramStudi Pascasarjana, Universitas Negeri Malang

Nemati, Azadeh. (2016). Portfolio Keeping Ends to a Good Product: The Cases of Reading and Motivation. ASIAN TEFL, 1(2), 2016

Parta, I.N. (2009). Pengembangan Model Pembelajaran Inquiry untuk Mempeluas Pengetahuan Matematika Mahasiswa Calon Guru melalui Pengajuan Pertanyaan. Disertasi tidak diterbitkan. Surabaya: UNESA.

Pickering, Blackburn and Moffet (1992). Dimensions of Learning.ASCD, 1250 N. Pitt St, Alexandria, VA 22314

Reiser, and Dempsey (2002). Trends ans Issues in Instructional Design and Technology. Upper Saddle River, New Jersey Columbus, Ohio.

Sukmadinata, N. S. (2010). Metode Penelitian Pendidikan. Bandung: PT Remaja Rosdakarya Offset.

Treiman, R. (2001). Reading. In M. Aronoff \& J. Rees-Miller (Eds.), Handbook of linguistics (pp. 664- 672). Oxford England: Blackwell.

Tunmer, W. E. (2008). Recent developments in reading intervention research: Introduction to the special issue. Reading and Writing: An Interdisciplinary Journal, 21, 299-316

Willis, J. and Wright, K.E. (2000). A General Set of Procedure for C-ID: the New R2D2 model. Educational Technology, Mar-Apr.5-20

Wilson (1995). Metaphors for Instruction: Why we talk about learning environment. Educational Technology, 35(5),25-30 